\title{
In Praise of Talent: Meritocracy and Social Justice in the Discourses of Grammar School Teachers: The Case of Sweden, 1927-1960 ${ }^{1}$
}

\author{
Ulla Johansson
}

This article seeks to analyze the discourses of education and social justice articulated in Tidning för Sveriges Läroverk (TFSL), the journal of the grammar school teacher union, during the period 1927-1960. I pose two questions: how teachers defined the ideal grammar school student, and what groups of students were thereby implicitly or explicitly excluded. In order to situate these discourses historically and socially, the first section of the paper will provide a broad outline of the rise of the Swedish educational system in the nineteenth century and the way discourses of social justice affected this process.

The theoretical framework used for the analysis is inspired partly by Foucault's genealogical method for discourse analysis and partly by Pierre Bourdieu's theories of capital and field. ${ }^{2}$ I have also used Joan W. Scott's model for the analysis of gender in order to understand how the social category of the grammar school student was constructed in the discourse of the grammar school teachers. $^{3}$

1 This study is part of a larger project financed by the Swedish Research Council for the Humanities and Social Sciences. Cf Ulla Johansson, Normalitet, klass och kön: Liv och lärande $i$ svenska läroverk 1927-1960 (Umeå, Umeå universitet, pedagogiska institutionen, 2000).

2 Cf. Michel Foucault, The Foucault Reader, ed. Paul Rabinow (Harmondsworth: Penguin Books, 1986); Rudi Visker, Michel Foucault: Genealogy as Critique (London, New York: Verso, 1995); Pierre Bourdieu, The Logic of Practice (Stanford: Stanford University, 1990); Pierre Bourdieu, The Field of Cultural Production (Cambridge: Polity Press, 1993).

3 See Joan W. Scott, Gender and the Politics of History (New York: Columbia University Press, 1989).

(C) Historical Studies in Education/Revue d'histoire de l'éducation 14, 1 ( 2002): 93-112 


\section{Social justice and the legitimacy of power}

The starting point for my study is the fact that Sweden, like most societies, is built on social hierarchies which in their turn are based on an unequal distribution of economical or cultural resources, privileges, and status. These inequalities can of course be upheld by violence, but more usually those who benefit from them try to make them appear as legitimate and just. In the premodern Swedish aristocratic society where privileges were connected to birth, they were justified by appeal to a divine right. However, in the nineteenth century this divine right began to be questioned. Rising bourgeois groups started to claim their share of power and privilege. With slogans like To each and everyone according to his merit, ${ }^{4}$ they attacked aristocratic supremacy. The path to the highest places in society should in principle, it was understood, be open to everyone, and those who reached the top should consequently be the most competent. According to such a meritocratic ideology, those who were privileged would have earned their privileges. The education system came to play an important role in this meritocracy; school marks were regarded as objective measures of personal merit and competence, and high marks and diplomas provided certification for top positions. ${ }^{5}$ In this respect the state grammar school played a crucial part. It was the main road not only to the universities but also to a number of different colleges, since a formal requirement for university or college studies was that the student had passed the final grammar school exam, the matriculation. ${ }^{6}$

4 As will be shown later, it is correct to use the pronoun "his," not "her," in this context.

5 Ulla Johansson, "Historien om likvärdighet i svensk skola," in Likvärdighet i svensk skola: En antologi (Stockholm: Skolverket, 1994).

6 In this respect there are striking similarities among many countries, even though different national contexts were also reflected in the educational systems. Cf. e.g. Detlef K. Müller et al., The Rise of the Modern Educational System: Structural Change and Social Reproduction 1870-1920 (Cambridge: Cambridge University Press, 1987); R.D. Gidney and W.P.J .Millar, Inventing Secondary Education: The Rise of the High School in Nineteenth-Century Ontario (Montreal \& Kingston: McGill-Queen's University Press, 1990); David F. Labaree, The Making of an American High School: The Credential Market and the Central High School of Philadelphia, 1838-1939 (New Haven: Yale University Press, 1988). 
Those who articulated these meritocratic ideas were obviously solidly convinced of their own ability. Their self-awareness was also solidly based on economic development; they all belonged to the vanguard of capitalism in Sweden. Capitalistic development started late in Sweden, but thereafter the pace accelerated. In a few decades Sweden was transformed from a basically agrarian country to a prominent industrialized nation. ${ }^{7}$ New times also required new moral and vocational qualifications - a new type of citizen had to be constructed. Sweden had to keep up with the competition on the international market, and it became the duty of the state to mobilize all citizens in that struggle. Education was one means for attaining this goal, and with the state apparatus as a platform a group of bourgeois men started systematically to build a modern school system. Old schools and curricula were reformed; for example, in grammar school more time was allocated to sciences and modern language at the expense of Latin and Greek. Advanced schools for the education of engineers, veterinarians, agronomists, and so on, were established. Investment in education was by way of investment in individuals, which later would be to the benefit of the state; but first and foremost, bourgeois groups would be the beneficiaries. $^{8}$

Thus, it is possible to distinguish two separate but related themes in the discourse of education, both generated out of the fundamental "truth" that the bourgeois social order is the natural order of things. The first theme concerned the relation between education, social justice, and meritocracy. A natural order must be just, and the truly meritocratic school system guaranteed that this was also the case. The second theme concerned social efficiency: the educational system distributed students to appropriate positions in society according to the principle, the right person in the right place. There were only winners and no losers in this system since everyone contributed to the common good. These themes proved

7 Rolf Torstendahl, “Technology in the Development of Society 1850-1980: Four Phases in Industrial Capitalism in Western Europe,” History and Technology (1984): 157-74.

8 Ulla Johansson and Christina Florin, "Young Men in Old Institutions: Culture, Class and Gender in Swedish Grammar Schools-A Comparative Perspective," Scandinavian Journal of History 18, 2, (1994): 192-96. 
to be very persistent in educational discourses, even if, later, the "truths" which were referred to in order to uphold the image of a socially just and efficient school system changed.

While many advanced schools were established in the nineteenth century, a system for mass education was also constructed. The first Elementary School Act was passed in 1842. It is true that the act was an indication of only the most modest ambitions of the state for popular education. For example, the school age was not fixed. The sole requirements were that school entrance must not be postponed later than the age of nine and that children had to stay in school until they had achieved minimal standards of skills and knowledge. However, by the end of the century elementary schooling had expanded and improved. The school age was now fixed, spanning the ages of seven to twelve, and the elementary school was divided into six forms. Furthermore, control over school attendance was also strengthened. Some form of elementary schooling became compulsory, but it was still possible to fulfil that duty by attending other forms of school like state grammar schools or private girls' schools. Nevertheless, an increasing proportion of Swedish youth spent an increasing part of their life in elementary schools all around the country. ${ }^{9}$

In his investigation of the birth of the modern prison, Foucault points to the fact that schools, like prisons, were important institutions for disciplining and controlling the people. ${ }^{10}$ Schools were to construct the new individual, a disciplined person who voluntarily submitted himself or herself to the order of things. According to their ranking and progress, students were allocated to different types of schools and classrooms within the schools. Examinations, classifications, rewards, and remedial treatments were normalising practices, which in their turn constructed patterns of normality. In these processes the individuals were objectified. But as far as they accepted the classification of themselves, their

9 Christina Florin and Ulla Johansson, "Three Cultures, Three Stories: Discipline in Grammar Schools, Private Girls' Schools and Elementary Schools in Sweden 18501900," in Discipline, Moral regulation, and Schooling: A Social History, ed. Kate Rousmaniere et al. (New York and London, 1997), 44.

10 Michel Foucault, Discipline and Punishment: The Birth of the Prison (New York: Penguin Books, 1982), 135-230. 
behaviours, thoughts, feelings, attitudes, and thus their identities were also constructed. ${ }^{11}$ In my view this also meant that the patterns of normality were differentiated. One pattern was established in, for example, the grammar school, and quite another in the elementary school.

To summarize: the educational system played a key role in establishing and legitimating a bourgeois hierarchical order. The school system was also employed by the new industrialized nation for competition on the international market. But education was, as well, a means of making everyone realize their proper place in the social division of labour. Most people were intended to learn to accept a subordinate position, while a few would become more strongly convinced that they deserved better than others, including a larger share of the good things of life. ${ }^{12}$

\section{Education, class, and gender}

In this section, I sketch out how the school system provided for classification of people into subordinated and superior subjects. In the nineteenth-century school system one can distinguish three different levels, corresponding to three levels of the vertical division of labour. The elementary school system with the elementary school as the basic unit would educate for subordinate positions in society. The junior secondary school prepared its students for intermediate positions in society. But unlike most of the vocational schools building on the elementary school, the lower secondary school was connected with the upper secondary grammar school and thus with higher education. The grammar school provided an academic education, and in contrast to, for example, the American high school, there was no streaming of the

11 James Marshall, “Michel Foucault: Governmentality and Liberal Education,” Studies in Philosophy and Education 14, 1 (1995): 23-34.

12 For the role played by Canadian elementary schooling in this process, see Bruce Curtis, Building the Educational State: Canada West, 1836-1871 (London, Ontario, Canada: The Falmer Press and The Althouse Press, 1988). 
students into vocational and academic study programs. ${ }^{13}$ The universities and the colleges were the third and last stepping stones to influential positions in the civil service as well as the world of industrial management, banking, and business. ${ }^{14}$

The system was also segregated by gender, but it is noteworthy that gender segregation was more obvious at the secondary level. The upper secondary grammar school was entirely a male world. A penniless young man could get in with the help of a grant and a benefactor, but the door was definitely closed for a girl, however wealthy she might have been. Paradoxically, higher education was not altogether dominated by men, since some programs accepted women students. However, it was not easy for a woman to qualify for university studies. She had either to be privately coached and examined as an external candidate at a grammar school or attend one of the few private girls' schools which were authorized to examine their students and confer the necessary matriculation diploma. The parents of the girls had to pay out of their own pockets for their daughters' secondary education, whereas boys could get such an education practically free of charge in the statefunded secondary grammar schools.

The basic structure of the education system strikes a discordant note with the meritocratic idea according to which the road to the highest positions in society should be open to each and every person. And as this road, with respect to education, passed through the grammar school, there is reason to examine which processes and discursive rules made it possible to preserve those rewards for a small group of young men. Here, the public opinion that the grammar schools in practice really were open to everyone played an important part. In the 1820s, for example, a state commission stated that the schools had always been free and should remain so in order to "give the cottager's son an opportunity to ascend to the most prestigious state positions by his own efforts, for the sake of

13 The junior grammar school was also the basis for various vocational schools on the upper secondary level, preparing for intermediate positions in the division of labour.

14 In this respect, the structure of the Swedish school system was very similar to those in other Western Countries. Cf Müller et al., The Rise of the Modern Educational System. 
glory and benefit of the nation." ${ }^{15}$ To be sure, there were some fees for firewood, light, and the school library, but a poor and talented boy could be exempted from these.

However, it should be noted that concern was directed only to the cottager's son, not to his daughter or to any other girls. The meritocracy was by definition a male enterprise, and there was obviously no need for justifying this state of affairs. The struggle for power and glory was a struggle among men. The exclusion of women from the arena stood to reason, and this matter of course was legitimated by the authority of old "divine truths" confirming that women were subordinate to men, and by laws and regulations asserting that women politically and legally were not, and could never be, real citizens. Thus, the modern meritocratic discourse about social justice presupposed and built on gender relations characteristic of the pre-modern society. However, it should be noted that the first inroads into the male educational monopoly had been made as universities and a few colleges had opened up for women. In the second half of the nineteenth century women were also granted some citizens' rights; for example, unmarried women on reaching the age of majority had control over their own property, and women also got the right to fill state positions on the intermediate level in post offices, elementary schools, etc.

Thus, according to the rhetoric the grammar school was open to every talented boy, but there were also statements revealing the exclusive nature of the system. In the 1870s the local fees for grammar school studies were raised, and state fees were also introduced. The arguments used for this decision was not very consistent with the meritocratic ideology: "Grammar school education is for the good of those who attend this school. Therefore, it is only fair that they should also share the costs of their privileges.” 16

15 Betänkande af Comitén för öfverseende af Rikets Allmänna Undervisningsverk den 29 December 1828 (1829), 25.

16 C.G. Hammarsköld, the Minister of Ecclesiastical and Educational

Affairs. Cited in Läroverkskomiténs underdåniga utlåtande och förslag angående organisationen av rikets allmänna läroverk (1884), 301. 
A modern meritocratic discourse was thus established, but it was mixed with pre-modern religious doctrines in order to legitimate the meritocracy as a preserve for bourgeois men. However, themes from modern medical discourses were also reflected in the idea that female biology disqualified women for great intellectual achievements and, what was worse, would doom them to succumb if they dared to compete with men on the labour market. ${ }^{17}$

However, at the end of the century such discursive themes started to dissolve. They were used to legitimate the social order, but many social democrats, liberals, and elementary school teachers now criticized the system for being socially unjust. They called attention to the injustice of providing different education for different social classes, and of secondary education being free for boys but not for girls. The remedy was a comprehensive coeducational elementary school for all Swedish children from the age of seven to twelve. In 1918 Värner Rydén, Minister of Educational and Ecclesiastical Affairs in the social democratic government, appointed a commission to create a democratic education system. In order to keep up with other countries in the world market, the nation had to take care of and develop all its talents. The interests of the nation were thus, as earlier noted, within the meritocratic discourse, but the need for more effective intellectual development had seemingly increased.

After much political compromise and manoeuvring, the school reform of 1927 was implemented, with two main consequences. Firstly, the grammar schools were opened to girls, and secondly, it was decided that a so-called "double connection" would be established, with the grammar schools continuing on from the fourth or sixth classes of the folkskola, the compulsory elementary school. The government would no longer subsidize other forms of education corresponding to the first four classes of the folkskola. The latter thus acquired the character of a four-year comprehensive school for all children, with the aim of broadening the social basis

17 Karin Johannisson, Den mörka kontinenten. Kvinnan, biologin och fin-de-siecle (Stockholm: Norstedt, 1994). 
of the grammar schools. As a consequence, grammar school education actually became less exclusive. ${ }^{18}$

\section{Sources and the model of analysis}

The reform of 1927 is one indication that the discourses and discursive practices that established and defined the category of "the normal grammar school" student had changed, and consequently new meanings were attached to this category. In the next section I will analyze how those meanings were constructed in the grammar school teachers' discourse and in the rules and regulations guiding daily life in school. I will apply Joan W. Scott's model of analysis, originally designed for the analysis of gender, to the category of grammar school students. According to Scott, the relations between the sexes are constituted on a number of different levels. On the symbolic level, "male" and "female" are associated with different cultural symbols, and on the normative level the meanings of male and female are encoded in systems of norms, laws, and regulations. A third level is that of institutions, where procedures and relations are structured around gendered principles. School is one example of such an institution, the labour market another. There is also a fourth level, the subjective one, where gender identities are developed. ${ }^{19}$

Scott's model would seem suitable to the analysis of social categories other than gender, and in what follows I apply it to the

18 About 25 per cent of students attended grammar school in the 1950s, even if four out of five of those students did not get as far as the matriculation. Cf Statistiska centralbyrån, Pupils in Swedish Secondary Schools in Sweden 1864-1970 (Stockholm, 1984), 69.

19 Other researchers have constructed similar models for the analysis of gender. According to Sandra Harding, gender has both a symbolic and structural as well as an individual dimension. According to Monica Bjerrum-Nielssen and Monika Rudberg, gender is constituted as structure, symbol, identity, and body. Cf. Sandra Harding, The Science Question of Feminism, (Milton Keynes: Open University, 1986); Monica Bjerrum-Nielssen and Monika Rudberg, "Når kjønnet kommer i skole-pedagogisk kvinneforskning,” in Forståelser av kjønn, ed. I. A Taksdal and Karin Widerbrg (Oslo: Gyldendahl, 1992). 
category of "the grammar school student.” The questions I will ask include: how was the secondary school student defined by the regulations which governed secondary school organization and everyday school procedure (the normative level)? Which meanings were encoded into the concept of "the grammar school student," and which groups were thereby conceptually excluded (the symbolic level)? Were the mechanisms of exclusion built into the institution/organization itself (the institutional level)?

My analysis is based chiefly on a systematic review of the publication Tidning för Sveriges läroverk (TFSL), a weekly organ of the grammar school teacher union, covering the period 1927$1960 .^{20}$ In this publication the official opinions of the union were articulated, and in this sense it represented the dominant discourses of the teachers. However, it also published, referred to and/or commented on reports of state investigations, and various teacher meetings. The journal was also a forum for teachers working in grammar schools, and many articles on different topics were written by adjuncts and senior lecturers.

All in all, my analysis is based on every article, editorial, report, and comment explicitly treating the issue of which student should or should not be worthy of attending the grammar school. The quotations used are thus representative of the journal. This is not necessary to say that they also are representative of the whole teacher body. It is more likely that the material published was selected in order to further elaborate and reinforce the dominant discourses of the teacher union, thereby silencing other voices.

Before turning to that analysis, I want to say a few words about the character of the teacher body. The vast majority of grammar school teachers were men, even if the proportion of women increased over time. Most of the teachers were also of middle-class origin, and traditionally they belonged to the local elite of the city in which the grammar school was located. Many of them also played an important part in public affairs, in Parliament, etc. ${ }^{21}$

20 Approximately 900 issues in all.

21 Cf Christina Florin and Ulla Johansson, "Där de härliga lagrarna gro...": Kultur, kön och klass I de svenska läroverken 1850-1914 (Stockholm: Tiden, 1993), 171-75. 


\section{The primacy of talent}

Various mechanisms operated on the normative, symbolic, and institutional levels in order to guarantee that the normal grammar school student belonged to the category of the talented few. Most important on the normative level was the meritocratic discourse. In 1927 echoes from the nineteenth century clearly resounded in the TSFL:

I often say to my students, that there is only one institution in Sweden where money and a distinguished name are of no avail, but where everyone is judged according to their abilities. That institution is a Swedish grammar school. ${ }^{22}$

The school system had thus always been socially just, and therefore the school reform of 1927 both literally and figuratively kicked in doors that were already open. However, there was no consensus on how the line between gifted or less gifted students was to be drawn. Nor, of course, were there any objective and historically unchanging criteria to go by; instead, to use Foucault's words, the "regime of truth" prevailed here, dictated by sciences like psychometrics. At the beginning of the period in question, talent was considered a rare item, a view which also legitimized the exclusivity of the grammar schools. In the 1940s, it was claimed that only 12.5 per cent of the population were capable of taking the matriculation, studentexamen. ${ }^{23}$

On the institutional level the discourse of meritocracy was manifested in school routines and practices. Testing and marking were procedures that left many students in no doubt that they were not gifted enough. Thereby they became marginalised, excluded, and transferred to the category of "the others." 24 Other excluding forms of practices were study counselling and the redirecting of

22 G. Björklund, quoted in TFSL no. 9 (1927): 145.

23 TFSL, no. 6 (1945): 99, report of a discussion held by the Association of Young Swedish Grammar School Teachers.

24 Ulla Johansson, "Coming up to the standard: normalising practices in Swedish grammar schools 1927-1960,” History of Education Review 30, 1 (2001): 43-59. 
failing students to vocational programs. On the normative level there were also strict rules for how to treat failing students. After having failed the yearly exam a second time, the student was expelled.

Many symbolic meanings served as excluding mechanisms. Mediocre students were to be denied access, or at the least, illiterates were to be stopped from getting in. Voices were raised in warning against "the old womanish namby pamby pedagogy which would turn grammar school into democratic nursing homes for less able students." 25

\section{The normal grammar school student in a class perspective}

The category of the normal grammar school student was thus supposed to include the most talented part of the Swedish youth. However, if we apply a class perspective, we can see how several mechanisms operated to exclude certain groups of students, regardless of how gifted they might have been. On the institutional level the very organization of schooling was to the disadvantage of young people of rural origin. Grammar schools were situated only in larger towns, and even if the so-called double connection aimed to assist students from the country in attending a grammar school, these students were under-represented in grammar school. ${ }^{26}$

On the normative level, stipulations that the student had to pay various fees had not been abolished. Consequently poor students faced difficulties in financing their education, even if it was still possible to be exempted from these fees or to get a scholarship. But to obtain a scholarship it was necessary for the student to behave well. If he or she did not get the highest mark in order and conduct, the scholarship was usually withdrawn. ${ }^{27}$

25 Editorial, TSFL no. 17 (1941): 257.

26 Due to the double connection between the elementary school and the grammar school, students could postpone the entrance into grammar school to the age of twelve instead of ten.

27 As part of the overall project, I have examined the practices of punishments and rewards in five grammar schools and found several examples of misbehaving students risking their grants. 
The category of the "normal grammar school student" was also given symbolic meanings which implicitly excluded working-class children. The child of university graduates was occasionally depicted as the ideal grammar school student, an image which was supported on the normative level by the theses of eugenics:

An erudite man ought reasonably to have a greater predisposition towards raising erudite children than businessmen, farmers and workers do. A cat gives birth to a cat, and a rat to rats, that is the law of nature. ${ }^{28}$

Obviously, strong cultural norms prescribed that the cobbler should stick to his last! Many symbolic meanings were attached to working class students which implicitly defined them as belonging to "the others." For example, working-class parents were at times depicted as obsessed with learning and status. There was a "superstitious belief in the value of theoretical studies, characteristic of our people and quite predominant among the lower levels of society." 29 But the most powerful metaphor was that of the spectre of the learned proletariat, symbolised by the workingclass student:

Moreover, it would be a disaster in the making should large numbers of working-class boys and girls go in for a university career. They do not have parents who can support them in case of unemployment. There is no point in the state throwing away millions of crowns to create such a situation..$^{30}$

\section{The normal grammar school student in a gender perspective}

28 Svenonius, TFSL no. 27 (1932): 365.

29 TFSL no. 20 (1931): 261.

30 Cederschiöld, quoted in TFSL no. 4 (1927): 57. 
A similar analysis may also be carried out in a gender perspective. On the institutional level it is important to note that gender segregation still remained within the school system. For example, girls' schools with a gender-specific curriculum were not abolished in 1927; rather, the Girls' School Act of 1928 promoted the establishment of a larger number of such schools in order to divert girls from higher studies, to hinder "yet another unwelcome suction of girls into the state grammar schools." 31 In some towns girls did not have access to the junior secondary school. There they were restricted to the girls' school of the town, which meant that they had to take private lessons in order to proceed to the upper secondary school for matriculation.

On the normative level certain political doctrines worked as means of inclusion. For example, education was declared a citizen's right, and women were now politically and legally defined as full citizens. Rules for scholarship were changed in order to include girls. ${ }^{32}$ The practice of testing seems to have been to the advantage of girls, as they performed better than boys at tests and exams. ${ }^{33}$

On the other hand, there were strong cultural norms prescribing that the woman's place was at home, and the talented grammar school student was symbolically constructed in such ways that girls were excluded. The female student was pictured as a symbol of a far too ambitious student, a busy Lizzie, risking her health by studying too hard. In short, the conscientious, careful young woman did not match the ideal of the normal grammar school student. Instead, the ideal seemed to be a boy who, by exhibiting a manly indolence in the first few years of grammar

31 The National Board of Education, cited in TFSL no. 3 (1930): $26 \mathrm{ff}$.

32 Many of the scholarships were stipulated by private donators to be for poor but talented boys, but state legislation made it possible to change the stipulations to include girls.

33 The proportion of boys failing to pass to the next form at the end of the school year was higher than for girls. The drop-out rate for boys was also higher than for girls. Cf. Johansson, Normalitet, kön och klass, 191, 373. 
school, demonstrated an "ability to conserve his energy for future work." ${ }_{34}$

But the arguments were surprisingly inconsistent. Young women were good at school, but they were not good in the right way. The same person who warned that a diligent girl ran the risk of over-exerting herself could also worry that "the temptation of the excessively many opportunities for dancing...will be too much for some girls.” ${ }_{35}$ Grammar school studies made the girls too good for housework, but they also became overworked because they - unlike the boys - had to help out at home as well, which was nonetheless "wholly beneficial" for them. ${ }^{36}$ No matter what the girls did, it seems, it was always the same old story...

\section{The normal grammar school student redefined}

These discourses were dominant in the TSFL before World War II, but from the mid-1940s on, new meanings were attached to the category of the normal grammar school student which made it less exclusive. For example, under the heading "Dinosaur in the Parliament," a member of the Swedish Parliament was criticized in an editorial for saying that those who could not afford to study ought instead to dig ditches. ${ }^{37}$ Previously, arguments taken, say, from racial biology had been used to shut working-class children out, but now it could instead be claimed that social mobility helped improve the quality of the upper class. ${ }^{38}$ It was the duty of society to give each and every one the education he or she demanded. The claim was even made that it was up to the parents-not the teachers - to decide whether their children were gifted or not.

The issue of gender disappeared completely from the debate. One explanation for this is probably the paradox of girls being at

\footnotetext{
34 Report of a discussion held by the Stockholm Teachers' Society, TFSL no. 20 (1941): 307.

35 TFSL no. 4 (1927): 59.

36 School doctor, as reported in TFSL no. 17 (1932): 223.

37 TSFL no. 1 (1955): 3-4.

38 Prof. Dahlberg, as reported in TFSL no. 4 (1942): 62.
} 
once discursively included and excluded in so many and contradictory ways. But discursive changes cannot be explained with reference only to the internal logic of the discourse. How, then, is it possible to understand the ruptures and conjunctures of various discursive themes, the breaks in social practices and symbolic meanings that contributed to the redefinition of the normal grammar school student? These questions will be dealt with in the final section.

\section{A field in transition}

The construction of a school system in the nineteenth century paved the way for the emergence of a pedagogical field, that is, a social field in Bourdieu's sense of the word. Different groups of teachers, politicians, and researchers became involved in the struggle over the field's values, and used discursive themes about access to grammar school studies as social strategies. Such themes can, according to Ingólfùr Jòhannesson, be grouped around a few legitimating principles, which have in previous struggles acquired symbolic capital and thereby been active in structuring the discourse of the field. ${ }^{39}$

As has been shown, two legitimating principles can be distinguished among the discursive themes dealing with access to grammar school studies: firstly, the principle of social justice and secondly, the principle of social efficiency. The principle of social justice was articulated within the distributive paradigm, that is, it was restricted to the morally proper distribution of benefits among

39 I want to express my gratitude to Ingólfùr Jòhannesson for his comments on an earlier draft of this paper. I will draw on his ideas in my analysis of the discursive shifts that I have identified in the teachers' discourse. In his investigation of school reforms in Iceland, Jòhannesson has combined Foucault's genealogical method for discourse analysis with Bourdieu's concept of capital and social field. See Ingólfùr Ásgeir Jòhannesson, "Genealogy and Progressive Politics: Reflections on the Notion of Usefulness,” in Foucault's Challenge: Discourse, Knowledge, and Power in Education, ed. Thomas S. Popkewitz and Marie Brennan (New York and London: Teachers College Press, Columbia University, 1998). 
the members of the society. ${ }^{40}$ In accordance with this paradigm, equal access to grammar school education was of vital importance. However, the idea was not that everyone should attend a grammar school. The meritocratic theme was also in play, legitimating restricted access: grammar school was only for gifted students. From this point of view, the selection of students had to be just, and according to many nineteenth-century teachers and politicians this was the case. "Proofs" were provided by religious doctrines and scientific findings that legitimated the exclusion of workingclass children and girls.

As mentioned above, the grammar school teachers belonged to the local elite. In my view, their high status was to a large extent due to the fact that they were supposed to educate the future elite of the society. Therefore it was crucial for them to preserve the exclusivity of the grammar school. The school reform of 1927 is an indication that the truths underpinning the discourse of meritocracy were seriously challenged, but still many of the teachers adhered to them. The argument was that talent was a rare item, and therefore it was only right and proper that the vast majority of Swedish youth were excluded. Gendered and socially biased selection was legitimated with reference to eugenics and psychological and biological theories of girls' ineligibility for higher education.

The principle of social efficiency was also mobilized in order to defend restricted access. It would be a disaster for the nation if women to a large extent entered the labour market, competing with men and, worse still, even winning that competition! In the interest of the nation the woman should first and foremost perform her natural role in life as a wife and mother. The spectre of the learned proletariat was also a social reality in the 1930s and, from the teachers' point of view, much could be won by keeping the grammar school doors locked against the masses. The issue at stake was to keep cultural capital exclusively institutionalized in the grammar school. This was more or less explicitly regarded as

40 Iris Marion Young, Justice and the Politics of Difference (Princeton, NJ: Princeton University Press, 1990), 15ff. 
necessary for the possibilities of converting cultural capital into high salaries and status on the labour market. As the teachers themselves belonged to the middle class, they had a vested interest in preserving the exclusiveness of grammar school. For example, it would make it easier for them to reproduce the cultural capital of their own families, as such a system was to the advantage of their own children.

However, after the end of the Second World War the demand for professionals grew, and at the same time qualification requirements were stiffened for many occupational groups. ${ }^{41}$ The spectre of the educated proletariat faded in a world where even "a cow owner nowadays has to know how to run a milking machine, judge the fatty content of the milk and know what is needed to increase it." 42

At that moment new themes were articulated in the teachers' discourse and a different strategy was employed in the struggle over the field. Teachers would no longer educate only a very restricted elite. They would now-in the spirit of human capital theory-attempt to guide the largest possible percentage of Swedish youth to the highest possible level of education. As dutiful servants of the industrial state, the teachers would happily try their best to raise the qualification level of the nation. This in itself was quite compatible with the meritocratic discourse enshrining the primacy of talent - the best would still be those who got the farthest.

This strategical shift was also "natural" from another point of view. The entire field of education was being restructured during this time. It was obvious that the period of compulsory school attendance was going to be lengthened, and the elementary school teachers now began to get involved seriously in the battle over the field's values. As a result, the old foe of the grammar school teachers, the educated proletariat, was replaced by elementary school teachers who "hanker after our positions, titles and

41 Rolf Ohlsson, Högre utbildning och demografisk förändring (Lund: Ekonomiskhistoriska föreningen, 1986), 57ff, 209.

42 Editorial,TFSL no. 17 (1947): $241 \mathrm{ff}$. 
imaginary perquisites." 43 The battle mainly concerned the right to teach at the lower secondary level, which is why the editorial columns of the TFSL advocated an early differentiation of students within the walls of the future comprehensive school and not, as before, at the portals of the junior grammar school. This shift illustrates how, in the words of Bourdieu, social strategies are generated by endless acts of recognition resulting in investments in the collective enterprise of creating symbolic capital. Even if the acts of recognition also generate a mis-recognition of what the struggle concerns, they are at any rate practical calculations that people make on the basis of a sense of which kind of strategies will be successful. ${ }^{44}$ This may be an explanation why the discursive themes changed in the TSFL without anyone noticing or commenting on the shift.

What could or could not be said was also determined by the power relations structuring the economical, political, and ideological field. In the nineteenth century powerful bourgeois groups were successful in claiming that the bourgeois meritocracy and education system was socially just. However, later on the labour movement and the social democrats challenged bourgeois hegemony in many spheres of society, and after World War II the Social Democrats came into power. ${ }^{45}$ And the dominant theme was now that the social order and school system was not socially just. Such statements became the truths of the new era. Many investigations of the social recruitment to higher education had been carried through, and they showed the socially biased nature of the system. The notion of the reserve of talent also constituted a powerful discourse, and much research was done in order to measure its proportions. The conclusion was that the proportion of the population capable of taking matriculation ought to be doubled in size compared to earlier estimations.

43 Valmin, TFSL no. 11 (1946): 178.

44 Pierre Bourdieu, The Logic of Practice (Stanford: Stanford University Press, 1990), $68 \mathrm{ff}$.

45 The Social Democrats had also been part of coalition governments between 1933 and 1945. 
Furthermore, the discursive themes which predominated in the TFSL during the 1930s were related to conservative doctrines which, by the end of the Second World War, had lost much of their credibility. Therefore truths provided by, for example, eugenics could not possibly be voiced any longer. When in addition the political decision-makers, i.e. the social democrats, explicitly assigned the school an important role in realizing their visions of the good society, the grammar school teachers could not afford to miss the train.

Finally, I want to point out that every single opinion quoted in this article is that of a man! Actually, only one woman teacher took part in the articulation of the meritocratic discourse in TFSL. ${ }^{46}$ However, I cannot tell whether this was because women were not engaged in the matter or because their voices were silenced by the editors. Women teachers were not absent in the columns of TFSL. For example, they played a role in the construction of certain forms of teacher authority, as they wrote in TFSL about matters of discipline and disruption of order in schools. ${ }^{47}$ But from its very start the meritocracy was a construction made by men, and I cannot help feeling that it continued to be so, even if one aim of the reform of 1927 was to integrate women into this construction and even if girls entering the grammar school were firmly determined to compete in the race and prove themselves as competent as the boys. ${ }^{48}$ However, to define and change the rules of the meritocratic game was still the venture of men.

46 Beth Hennings, TFSL no. 15 (1936). Hennings was the headmaster of a grammar school for girls. In the article she argued against the proposal of the Minister of Education and Ecclesiastical Affairs, according to which domestic science should be compulsory for girls in grammar schools. In her view, grammar school education should be a preparation for a career for both girls and boys.

47 Ulla Johansson, "Police or pal? Changing notions of Swedish grammar school teachers' authority 1927-1960,” paper presented at the AARE conference, Brisbane, December 1997.

48 Johansson, Norma litet, kön och klass, 176-98. 